\title{
Cortinarius subsalor and C. tibeticisalor spp. nov., two new species from the section Delibuti from China
}

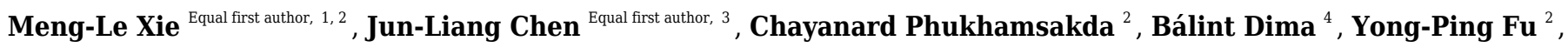 \\ Rui-Qing Ji ${ }^{2}$, Ke Wang ${ }^{5}$, Tie-Zheng Wei ${ }^{\text {Corresp., } 5}$, Yu Li ${ }^{\text {Corresp. 1, } 2}$ \\ 1 Life Science College, Northeast Normal University, Changchun, Jilin, China \\ 2 Engineering Research Center of Edible and Medicinal Fungi, Ministry of Education, Jilin Agricultural University, Changchun, Jilin, China \\ 3 Science and Technology Research Center of Edible Fungi, Lishui, Zhejiang, China \\ 4 Department of Plant Anatomy, Institute of Biology, Eötvös Loránd University, Budapest, Hungary \\ 5 State Key Laboratory of Mycology, Institute of Microbiology, Chinese Academy of Sciences, Beijing, China \\ Corresponding Authors: Tie-Zheng Wei, Yu Li \\ Email address: weitz@im.ac.cn, liyu@jlau.edu.cn
}

Cortinarius subsalor and C. tibeticisalor, belonging to the section Delibuti, are described from China as new to science. Cortinarius subsalor has been found to be associated with Lithocarpus trees in subtropical China and resembling C. salor, but it differs from the later by having slender basidiomata and the narrower basidiospores. Cortinarius tibeticisalor was collected from eastern Tibetan Plateau, associated with Abies. It differs from other species within sect. Delibuti by having olive tinge of mature or dried basidiomata and bigger basidiospores. The molecular data also support $C$. subsalor and $C$. tibeticisalor as new species. The phylogenetic analyses and biogeography of sect. Delibuti are discussed and a key to the species of this section currently known in the world is provided. 


\section{Cortinarius subsalor and C. tibeticisalor spp. nov., two} 3 new species from the section Delibuti from China

Meng-Le Xie ${ }^{1,2 \dagger}$, Jun-Liang Chen ${ }^{3 \dagger}$, Chayanard Phukhamsakda ${ }^{2}$, Bálint Dima ${ }^{4}$, Yong-Ping $\mathrm{Fu}^{2}$, Rui-Qing Ji², Ke Wang ${ }^{5}$, Tie-Zheng Wei ${ }^{5}, \mathrm{Yu} \mathrm{Li}^{1,2}$

${ }^{1}$ Life Science College, Northeast Normal University, Changchun, Jilin, P. R. China

${ }^{2}$ Engineering Research Center of Edible and Medicinal Fungi, Ministry of Education, Jilin Agricultural University, Changchun, Jilin, P. R. China

${ }^{4}$ Department of Plant Anatomy, Institute of Biology, Eötvös Loránd University, Budapest, Hungary

\section{$\dagger$ These authors contributed equally to this work.}

Corresponding Author:

\section{$\mathrm{Yu} \mathrm{Li}{ }^{1,2}$}

Xincheng Street, Changchun, Jilin, 130118, P. R. China

Email address: liyu@jlau.edu.cn

Tie-Zheng $\mathrm{Wei}^{5}$

Beichen West Road, Chaoyang, Beijing, 100101, P. R. China

Email address: weitz@im.ac.cn

\section{Abstract}

Cortinarius subsalor and C. tibeticisalor, belonging to the section Delibuti, are described from China as new to science. Cortinarius subsalor has been found to be associated with Lithocarpus trees in subtropical China and resembling C. salor, but it differs from the later by having slender basidiomata and the narrower basidiospores. Cortinarius tibeticisalor was collected from eastern Tibetan Plateau, associated with Abies. It differs from other species within sect. Delibuti by having olive tinge of mature or dried basidiomata and bigger basidiospores. The molecular data also support $C$. subsalor and C. tibeticisalor as new species. The phylogenetic analyses and biogeography of sect. Delibuti are discussed and a key to the species of this section currently known in the world is provided.

\section{Introduction}


39

40

41

42

43

44

45

46

47

48

49

50

51

52

53

54

55

56

57

58

59

60

61

62

63

64

65

66

67

68

69

70

71

72

73

74

75

76

77

Cortinarius (Pers.) Gray is an ectomycorrhizal fungal genus, associated with a wide host range

of plants, such as Betulaceae, Caesalpiniaceae, Cistaceae, Dipterocarpaceae, Fagaceae, Myrtaceae, Pinaceae, Rhamnaceae, Rosaceae, Salicaceae and some herbaceous plants (Frøslev, Brandrud \& Jeppesen, 2006; Niskanen, 2008). The genus is distributed worldwide with nearly 3000 species (Niskanen et al., 2018; Ammirati et al., 2021; Bidaud et al., 2021). Even though it is the largest genus among macrofungi, its species diversity is still unclear. Most of Cortinarius species were originally discovered from Europe and America but rarely in Asia and Africa (Horak, 1983; Garrido-Benavent et al., 2020; Xie et al., 2020). Several systems of subgenus and sections in Cortinarius are erected based on the macromorphology of geographically limited samplings, but these are not supported by phylogenetic studies (e.g. Fries, 1838; Trog, 1844; Orton, 1955; Bidaud et al., 1994; Garnica, Weiß \& Oberwinkler, 2003; Garnica et al., 2005; Harrower et al., 2011; Stensrud et al., 2014; Niskanen et al., 2015; Garnica et al., 2016; Soop et al., 2019). For example, Garnica et al. (2005) proposed natural classification system in Cortinarius involving the taxonomic rearrangement of the species into eight informal clades. Soop et al. (2019) presented a section-based taxonomy of Cortinarius based on four loci of a large global sampling.

Cortinarius sect. Delibuti (Fr.) Sacc. with characteristics of viscid pileus and stipe, have usually been considered as a section in subg. Myxacium (Fr.) Trog (Trog, 1844; Earle, 1902; Orton, 1955; Brandrud et al., 1989; Consiglio, Antonini \& Antonini, 2003). Delibuti species can easily be distinguished by the anomaloid appearances, mild taste and subglobose basidiospores from other myxacioid species (Orton, 1955; Soop, 2014). Section Delibuti was also considered to belong to subg. Phlegmacium (Fr.) Trog (Bidaud, Moënne-Loccoz \& Reumaux, 1992; Bidaud, Moënne-Loccoz \& Reumaux, 1994). Recently, Soop et al. (2019) treated sect. Delibuti among anomaloid sections, not in myxacioid sections based on the shared characters of sect. Delibuti and sect. Anomali Konrad \& Maubl., together with support in the phylogenetic analyses. In the past, numeral species were assigned to section Delibuti (Fries, 1838; Earle, 1902; Bidaud, Moënne-Loccoz \& Reumaux, 1992; Soop, 2013; Soop, 2014), however most species have been confirmed not to belong to this section (Orton, 1955; Consiglio, 2012; Dima et al., 2016; Soop et al., 2019). Soop et al. (2019) defined only ten species in sect. Delibuti, but the phylogenetic studies showed that the species diversity of this section is still unrevealed (Harrower et al., 2011; Garnica et al., 2016; Soop et al., 2019).

In China, over 237 Cortinairus species, including several new species, have been described from China (Wei \& Yao, 2013; Xie et al., 2019; Xie et al., 2020; Xie et al., 2021; Yuan et al., 2020; Luo \& Bau, 2021). Four species within sect. Delibuti, C. betulinus J. Favre from Heilongjiang, C. delibutus Fr. from Heilongjiang, Jilin, Qinghai, Sichuan and Yunnan, $C$. illibatus Fr. from Ningxia, and C. salor Fr. from Heilongjiang, Jilin, Liaoning and Inner Mongolia, were reported (e.g. Teng, 1963; Yuan \& Sun, 1995; Shao \& Xiang, 1997; Li \& Azbukina, 2011; Xie, 2018; Wang et al., 2020), but the occurrence of species in China is controversial due to the lack of voucher specimens. 
78

79

80

81

82

83

84

85

86

87

88

89

90

91

92

93

94

95

96

97

98

99

100

101

102

103

104

105

106

107

108

109

110

111

112

113

114

115

116

117

In this study, we have conducted taxonomic and phylogenetic studies of Cortinairus in China. Some glutinously violet Cortinarius specimens resembling C. salor were found during the intensive field work but during the identification process they turned out to be new species which we describe here based on morphological and ecological characteristics, as well as phylogenetic analyses evidences. We also discuss the phylogenetic relationship and biogeography of sect. Delibuti. A key is provided the species of sect. Delibuti.

\section{Materials \& Methods}

\section{Specimens and morphological description}

Specimens were collected from Zhejiang Province and Tibet Autonomous Region, respectively. The collection sites in Zhejiang are the subtropical areas with the evergreen broadleaf forests dominated by Lithocarpus brevicaudatus. Meanwhile, the collection sites in Tibet are the plateau-alpine areas with coniferous forests dominated by Abies georgei var. smithii. Fresh basidiomata were photographed in the field. Dried specimens were deposited in the Herbarium of Mycology, Jilin Agricultural University (HMJAU), Changchun, China. Macroscopic characteristics were measured and recorded for every basidiomata and color codes followed Kornerup \& Wanscher (1978). Microscopic features were examined and described in $5 \% \mathrm{KOH}$, Congo Red or Melzer's reagent and observed using a Zeiss AX10 light microscope. Thirty to forty mature basidiospores were measured (excluding apiculus and ornamentation) per collection. $\mathrm{Q}=$ variation in the $\mathrm{L} / \mathrm{W}$ ratios between the specimens studied. $\mathrm{X}_{\mathrm{av} .}$ and $\mathrm{Q}_{\mathrm{av} .}=$ average value of basidiospores of per specimen.

\section{Phylogenetic reconstruction}

DNA extraction, PCR amplifications, and sequencing methods followed Xie et al. (2019) and Guan \& Zhao (2020). The primers ITS1F and ITS4 were used amplification of nrDNA ITS region (White et al., 1990; Gardes \& Bruns, 1993). The newly generated ITS sequences were submitted to GenBank. The ITS sequences for the phylogenetic analyses were selected based on results of BLASTn (> 90\% identity) in GenBank and UNITE and followed the publication by Garnica et al. (2016) and Soop et al. (2019). Two species in section Cyanites Nespiak were chosen as outgroup followed Xie et al. (2021).

Sequences (Table 1) for the phylogenetic analyses were aligned and edited with BioEdit 7.1.3.0 and Clustal X (Tompson et al., 1997; Hall, 1999). For phylogenetic analyses, Bayesian Inference (BI), Maximum Likelihood (ML) and Maximum Parsimony (MP) methods were implemented in this study. MrModeltest 2.3 was used to calculate the best model $(\mathrm{HKY}+\mathrm{I}+\mathrm{G})$ for BI analysis (Nylander et al., 2008). The BI analysis was performed with MrBayes 3.2.6 (Ronquist \& Huelsenbeck, 2003). Four Markov chains were run for 500000 generations until the split deviation frequency value $<0.01$, and sampled every 100th generation. The posterior probability values were estimated from the samples after discarding the first $25 \%$ (1250) generations. A 50\% majority rule consensus tree of all remaining trees were calculated. RAxML 
118 v. 1.5, implemented in raxmlGUI, were used to construct a ML tree, with a rapid bootstrapping

119 algorithm involving 1,000 replicates (Silvestro \& Michalak, 2012; Stamatakis, 2014). All

120 parameters in the ML analysis were kept as defaults except for GTRGAMMA were chose as the

121 model. The MP analysis was conducted in MEGA X (Kumar et al., 2018). The most

122 parsimonious tree with length $=1012$ is shown. The consistency index is $(0.442350)$, the

123 retention index is $(0.708912)$, and the composite index is $0.355860(0.313587)$ for all sites and

124 parsimony-informative sites (in parentheses). The bootstrap test was performed 1000 replicates

125 (Felsenstein, 1985). The MP tree was obtained using the Tree-Bisection-Regrafting (TBR)

126 algorithm (Nei \& Kumar, 2000) with search level 3 in which the initial trees were obtained by

127 the random addition of sequences (10 replicates). The phylogenetic trees were visualized in

128 FigTree 1.4.3. The Bayesian posterior probabilities values (BPP) $\geq 0.95$, ML bootstrap values

$129(\mathrm{ML}) \geq 75 \%$ or MP bootstrap values (MP) $\geq 75 \%$ are shown on the branches at the nodes

130 (BPP/ML/MP).

131

132

133

134

135

\section{Nomenclature}

The electronic version of this article in Portable Document Format (PDF) will represent a published work according to the International Code of Nomenclature for algae, fungi, and plants, and hence the new names contained in the electronic version are effectively published under that

136

137

138

139

140

141

142

143

144

145

146

147

148

149

150

151

152

153

154

155

156

157 Code from the electronic edition alone. In addition, new names contained in this work have been submitted to MycoBank from where they will be made available to the Global Names Index. The unique MycoBank number can be resolved and the associated information viewed through any standard web browser by appending the MycoBank number contained in this publication to the prefix "http://www.mycobank.org/MycoTaxo.aspx?Link=T\&Rec=". The online version of this work is archived and available from the following digital repositories: PeerJ, PubMed Central, and CLOCKSS.

\section{Results}

\section{BLASTn Results}

The BLASTn against GenBank and UNITE databases taked the holotype specimens as the examples. The BLASTn results showed that these two new species distinct from other members of Cortinarius and close to sect. Delibuti. The ITS sequence of C. subsalor (MW911734, holotype) has $99 \%$ identity with $C$. salor (MK250915). Here we addressed it as $C$. subsalor. The percent identity of C. subsalor with C. salor s.l. (AY669592, UDB015945) and C. delibutus (FJ717515) are 96\% and 95\%, respectively. The ITS sequence of C. tibeticisalor (MW911729, holotype) has 93\%, 91\%, 90\% identity with Cortinarius sp. (LC098750), C. delibutus (FJ717515) and C. tessiae (JQ287698), respectively.

\section{Phylogenetic analyses}

The matrix contained 66 ITS sequences with 767 nucleotide sites is available from TreeBASE under S28399 (Reviewer access URL: 
158 http://purl.org/phylo/treebase/phylows/study/TB2:S28399?x-access-

159

160

161

162

163

164

165

166

167

168

169

170

171

172

173

174

175

176

177

178

179

180

181

182

183

184

185

186

187

188

189

190

191

192

193

194

195

196

197

code $=430 \mathrm{ac} 181$ ef5e5126e7e216652a7edf71\& format $=\mathrm{html})$. The BI, ML and MP results showed similar topologies and ML tree was selected as the backbone phylogeny (Figure 1). The phylogenetic analyses showed 11 sections including one singleton species from Argentina, and two singletons from New Zealand. Every section formed separate monophyletic lineages with strong statistical support. Section Delibuti formed a distinct clade $(B P P=0.96)$ separate from other sections. Section Delibuti split into five main clades based on the analyses of ITS sequences. Clade A and B consist of Australasian species. Clade C is a clade including our new species from the Tibetan Plateau. Clade D consist of the species distributed in Europe, Asia and North and South America. Clade E represents species in the Northern Hemisphere. Cortinarius subsalor $(\mathrm{BPP} / \mathrm{ML} / \mathrm{MP}=1.00 / 100 \% / 100 \%$, clade $\mathrm{E})$ and $C$. tibeticisalor $(\mathrm{BPP} / \mathrm{ML} / \mathrm{MP}=$ $1.00 / 100 \% / 100 \%$, clade C) formed a dinstinct lineages with high statistical support, respectively. Furthermore, C. subsalor formed a sister relationship with the European C. salor $(\mathrm{BPP}=0.97$, clade E).

\section{Taxonomy}

Cortinarius subsalor M.L. Xie, T.Z. Wei \& Y. Li, sp. nov.

MycoBank No. MB839320

(Fig. 2)

Etymology. The name refers to its affinity to Cortinarius salor.

Holotype. CHINA. Zhejiang: Baishanzu Mountain, Qingyuan county, on moist soil under Lithocarpus brevicaudatus (Fagaceae) forest with scattered Theaceae and Rhododendron, $27^{\circ} 45^{\prime} 44^{\prime \prime} \mathrm{N}, 119^{\circ} 11^{\prime} 50^{\prime \prime}$ E, ASL 1510 m, 20 July 2020, Jun-Liang Chen, $Q Y-0235(1192-1198$ ) (HMJAU48759), GenBank: MW911734.

Diagnosis. Pileus hemispherical to plane, violet, glutinous; lamellae violet at first, then turning pale grayish violet; stipe slender, pale violet, then brown; glutinous veil violet. Basidiospores on average 8.0-8.3 $\times 6.9-7.0 \mu \mathrm{m}$, subglobose to broadly ellipsoid. Differing from other species in sect. Delituti by the violet color of basidiomata, the distribution of subtropical China and association with Lithocarpus brevicaudatus.

\section{Description}

Pileus 20-50 mm, hemispherical at first, then convex to applanate; bluish violet (18B6-18C7) at first, purple (15B6-15C7) to purplish red (14A6-14B7) at the centre, then grayish violet (17B417C5), pale violet (19A3) at the margin; surface glutinous. Lamellae emarginate; moderately crowded; violet (17B6) when young, then grayish violet (17B4-17C5) to pale grayish violet (15B1-15C2); edge almost even. Stipe slender, 35-65 mm long, 3-7 mm thick, clavate at base (up to $14 \mathrm{~mm}$ ); pale violet to grayish violet (19A3-19B5), later whitish, lightly brown to brown (7D6-7E7); surface with viscid universal veil, basal mycelium white with bluish tinge. Universal veil viscid, violet, remnants forming a girdle on the upper part of the stipe, disappearing with age. Context whitish at the pileus, slightly with yellowish tinge at the center, pale violet tinge

Peer) reviewing PDF | (2021:05:61287:1:1:NEW 11 Jul 2021) 
198

199

200

201

202

203

204

205

206

207

208

209

210

211

212

213

214

215

216

217

218

219

220

221

222

223

224

225

226

227

228

229

230

231

232

233

234

235

236

237

extend outward, hygrophanous near lamellae; white with pale violet tinge at the apex of the stipe, yellow at the lower part; somewhat hollow within stipe. Odor not significant, taste mild.

Basidiospores 7.7-9.5 (10.6) × 6.2-7.7 (8.7) $\mu \mathrm{m}, \mathrm{Q}=1.10-1.29$ (holotype), $\mathrm{X}_{\mathrm{av} .}=8.0-8.3 \times$ 6.9-7.0 $\mu \mathrm{m}, \mathrm{Q}_{\mathrm{av} .}=1.20$, subglobose to broadly ellipsoid, moderately coarsely verrucose, moderately dextrinoid. Basidia 4-spored. Lamellar edges fertile. Pileipellis: epicutis strongly gelatinous, about $180-250 \mu \mathrm{m}$ thick, with hyphae 2-7 $\mu \mathrm{m}$ wide, yellowish to colorless in 5\% $\mathrm{KOH}$, some hyphae with small encrusted granules. Hypodermium present; hypodermial hyphae 4-10 $\mu \mathrm{m}$ wide, cylindrical, almost colorless in 5\% KOH, smooth. Clamp connections present.

Exsiccatae. Pileus grayish violet (19B3-19C4) at the margin, light brown to dark brown (6D6-6F8) at the centre; lamellae rust brown (6E8); stipe brown (6D7-6E7), lighter downwards, yellowish white (4A2) at base.

ITS sequence. The ITS sequence of the holotype is distinct from other members of sect. Delibuti and deviating from them by at least 22 substitutions and indel positions.

Ecology and distribution. In subtropical evergreen broadleaf forests, associated with Lithocarpus brevicaudatus (Fagaceae). Known from Zhejiang and Hunan province of China.

Additional specimens examined. CHINA. Zhejiang: Baishanzu Mountain, Qingyuan county, on moist soil under Lithocarpus brevicaudatus (Fagaceae) forest with scattered Theaceae

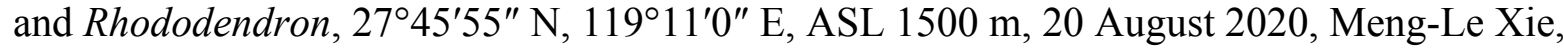
$20 x m l 12101$ (HMJAU48758), GenBank: MW911733.

\section{Cortinarius tibeticisalor M.L. Xie, T.Z. Wei \& Y. Li, sp. nov.} MycoBank No. MB839321

(Fig. 3)

Etymology. The name refers to the Tibetan Plateau, the type locality, and its similarity to $C$. salor.

Holotype. CHINA. Tibet Autonomous Region: Sejila Mountain, Linzhi city, on moist soil in Abies forest with scattered Rhododendron, 29³5'26" N, 94³5'53" E, ASL 4120 m, 5 September 2020, Meng-Le Xie, 20xml12416 (HMJAU48764), GenBank: MW911729.

Diagnosis. Pileus hemispherical to applanate, violet, glutinous, margin wavy, somewhat olive when mature; lamellae for a long time violet, then pale grayish violet to violet gray; stipe robust, bluish gray to brown with olive tinge; veil glutinous, violet. Basidiospores on average $10.3-10.8 \times 8.7-8.9 \mu \mathrm{m}$, subglobose to broadly ellipsoid, rarely ellipsoid. Differing from other species in sect. Delituti by the olive tinge of basidiomata and the large basidiospores.

\section{Description}

Pileus 50-85 mm, hemispherical at first, then convex to plane, sometimes slightly depressed, wavy at margin of mature basidiomata, violet (17C7) at first, especially at the centre, paler violet towards the margin, then grayish orange (5B5) to brown (5D6-5E7) with olive tinge, dark at the centre; surface glutinous. Lamellae emarginate, moderately crowded, persistently violet (17C7), then grayish violet (19B4-19C6) to violet gray (19B2); edge uneven, slightly serrate. Stipe $85-120 \mathrm{~mm}$ long, $10-15 \mathrm{~mm}$ thick, clavate at base (up to $23 \mathrm{~mm}$ ); surface with 
238

239

240

241

242

243

244

245

246

247

248

249

250

251

252

253

254

255

256

257

258

259

260

261

262

263

264

265

266

267

268

269

270

271

272

273

274

275

276

viscid bluish gray (19B2) universal veil remnants, then becoming yellow to brown with olive tinge (4B6-4D7), grayish violet (19B4-19C6) at the apex; basal mycelium white. Universal veil viscid, violet, remnants forming a girdle on the upper part of the stipe, dispearing with age. Context white with marbled violet tinge at first, slightly yellowish from the center of the pileus, then yellow at the stipe, especially at the middle. Odor weak when fresh, somewhat like honey when old or dry. Taste mild.

Basidiospores 9.7-10.9 (12.6) × 7.7-9.0 (10.0) $\mu \mathrm{m}, \mathrm{Q}=1.13-1.30$ (holotype), $\mathrm{X}_{\mathrm{av} .}=10.3-$ $10.8 \times 8.7-8.9 \mu \mathrm{m}, \mathrm{Q}_{\mathrm{av} .}=1.20-1.23$, subglobose to broadly ellipsoid, rarely ellipsoid, moderately coarsely verrucose, weakly dextrinoid. Basidia 4-spored. Lamellar edges fertile, with narrow clavate cells. Pileipellis: epicutis strongly gelatinous, about 300-410 $\mu \mathrm{m}$ thick, hyphae 3$8 \mu \mathrm{m}$ wide, with yellowish intracellular pigment in $5 \% \mathrm{KOH}$, smooth. Hypodermium present, hyphae 7-15 $\mu \mathrm{m}$ wide, irregular, almost colorless in $5 \% \mathrm{KOH}$, smooth. Clamp connections present.

Exsiccatae. Pileus olive brown (4E6-4F7) at margin, yellowish brown (5D7-5E8) at centre; lamellae dark bluish gray (19E2-19F2); stipe bluish white at apex, light brown (6D6-6E7) to dark brown (6F4-6F8), white at base.

ITS sequence. The ITS sequence of the holotype is distinct from other members of sect. Delibuti and deviating from them by at least 40 substitutions and indel positions.

Ecology and distribution. In plateau-alpine coniferous forests, associated with Abies (Pinaceae) trees. Known from Tibetan Plateau of China.

Additional specimens examined. CHINA. Tibet Autonomous Region: Sejila Mountain, Linzhi city, on moist soil under Abies forest with scattered Rhododendron, 29 $35^{\prime} 25^{\prime \prime} \mathrm{N}$, 94³5'55" E, ASL 4170 m, 28 August 2019, Meng-Le Xie, 19xml10976 (HMJAU48761), GenBank MW911731, 19xml10981 (HMJAU48762), GenBank MW911732; Sejila Mountain, Linzhi city, on moist soil under Abies forest with scattered Rhododendron, 29 $35^{\prime 2} 6^{\prime \prime} \mathrm{N}$, 943'ㄷ'ㄹ E, ASL 4120 m, 5 September 2020, Meng-Le Xie, 20xml12395 (HMJAU48763), GenBank: MW911730.

\section{Key to species of sect. Delibuti}

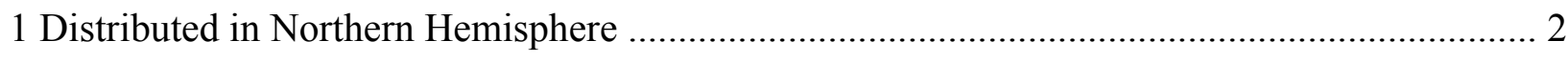

- Distributed in Southern Hemiphere

\section{9}

2. Pileus usually yellowish to ochraceous without blue

3

- Pileus more or less violet to blue when young, sometimes partly yellow 4

3. Lamellae usually blue when young, veil yellowish C. delibutus

- Lamellae pinkish ochraceous clay, veil not yellowish C. illibatus 
277 4. Pileus frankly blue when young, stipe bluish, veil violet

278 .5

279 - Pileus grayish blue to olive brown, stipe pale, veil different

2807

281 5. Basidiomata usually small, lamellae violet, then grayish to brownish, stipe usually slender $(<$

$28210 \mathrm{~mm}$ ), base white with bluish tinge, basidiospores on average 8.0-8.3 $\times 6.9-7.0 \mu \mathrm{m}$,

283 subglobose to broadly ellipsoid, distributed in subtropical China, associated with Lithocarpus

284 brevicaudatus C.

285 subsalor

286 - Basidiomata usually bigger, lamellae persistently lilaceous or bluish, stipe usually more robust

287 ( $>10 \mathrm{~mm}$ thick) 6

288 6. Pileus usually staining buff or fading from the centre, stipe base usually grayish brown,

289 basidiospores 7-9 × 6-8 $\mu \mathrm{m}$, globose to subglobose, distributed in Europue, associated with

290 deciduous and coniferous trees C.

291 salor

292 - Pileus usually olive brown when mature, stipe base usually white, basidiospores 10.3-10.8 $\times$

293 8.7-8.9 $\mu \mathrm{m}$, subglobose to broadly ellipsoid, rarely ellipsoid, distributed in Tibetan Plateau of

294 China, associated with Abies

C. tibeticisalor

295 7. Basidiomata small, pileus yellow to olive-ochre at the centre, grayish blue towards the margin, 296 soon fading, veil yellow, basidiospores 7.5-9.5 × 6.5-7.5 $\mu \mathrm{m}$, subglobose, associated with

297 Betula C.

\section{8 betulinus}

299 - Basidiomata robust, associated with coniferous forests

3008

301 8. Pileus usually olive brown with a violet margin, veil olive brown, basidiospores $8-10 \times 7-8$

302 $\mu \mathrm{m}$, globose, associated with Picea

C.

303 transiens

304 - Pileus not olive brown, but prefer orange tinge, basidiospores $7.5-9.5 \times 6.5-7.5 \mu \mathrm{m}$, subglobose,

305 usually associated with Abies, rarely occur in Picea forests. C.

306 largodelibutus

307 9. Associated with Nothofagus

$308 \quad 10$

309 - Associated with Myrtaceae trees

$310 \quad 11$

311 10. Pileus viscid, blue-green to aerugineous, stipe blue green, basidiospores $6.5-8.5 \times 6-7 \mu \mathrm{m}$,

312 subglobose, destributed in Australasia C.

313 tessiae

314 - Pileus glutinous, greyish yellow to greyish orange, stipe violet, then becoming white to pale

315 brownish, basidiospores ellipsoid, destributed in North and South America ................... C.

316 illitus 
317 11. Basidiomata distinctly viscid to glutinous, mainly greyish blue-green, basidiospores $7-9 \times 7-$

$3188 \mu \mathrm{m}$, globose to subglobose

C. rotundisporus

319 - Basidiomata weakly viscid, stipe often dry, mainly yellow-green to olive, Veil orange to

320 ochraceous, basidiospores $6-7.5 \times 5.5-6.5 \mu \mathrm{m}$, subglobose C.

321

322

323

324

325

326

327

328

329

330

331

332

333

334

335

336

337

338

339

340

341

342

343

344

345

346

347

348

349

350

351

352

353

354

355

356

\section{calaisopus}

\section{Discussion}

Cortinarius subsalor is similar to C. betulinus, C. salor and C. transiens (Melot) Soop due to the bluish tinge of the basiodiomata. However, $C$. betulinus is usually grayish blue at the margin of the pileus and soon fading, the stipe is often pale and the veil usually is yellow (Kibby, 2005; Niskanen et al., 2008; Soop, 2014). The pileus of C. transiens has a violet tone towards the margin, while the centre is more olive gray to yellowish brown even in young specimens, the stipe is pale, and the gelatinous veil is olive brown (Soop, 1990; Soop, 2014). In China, sometimes some bluish myxacioid species have been misidentified as C. salor (MHHNU30409, GenBank: MK250915), collected from Hunan Province. Our phylogenetic analyses showed that this sequence belong to the new species C. subsalor. Cortinarius salor has persitently lilaceous lamellae, the stipe is more robust ( $>10 \mathrm{~mm}$ thick) and the base is more grayish brown, the basidiospores are rounder $(7-9 \times 6-8 \mu \mathrm{m})$, and it occurs in European woodlands (Orton, 1955; Consiglio, Antonini \& Antonini, 2003; Soop, 2014). Based on these features, C. salor can be distinguished from the Asian C. subsalor.

Cortinarius tibeticisalor is characterized by the basidiomata usually violet when young, then grayish orange to brown with an olive tinge, larger basidiospores and a restricted distribution in the Tibetan Plateau. Cortinarius tibeticisalor is similar to C. salor in young stage, however, the basidiospores $(7-9 \times 6-8 \mu \mathrm{m})$ of $C$. salor are significantly smaller and rounder, and the basidiomata never have olive tinge (Orton, 1955; Consiglio, Antonini \& Antonini, 2003; Soop, 2014).

According to our phylogenetic analyses, sect. Delibuti demonstrates a widely distributed lineage of Cortinarius, in both the Northern and Southern Hemispheres. This bihemispherical distribution is also seen in several other lineages in Cortinarius, such as Anomali, Bolares, Camphorati, Defibulati, Illumini, and Vibratiles, this is concordant with other studies (e.g. Harrower et al., 2015; Garnica et al., 2016; Soop et al., 2019). The nrDNA ITS region is not suitable to draw conclusions for comprehensive phylogenetic evaluation, however, there are some interesting patterns indicated in sect. Delibuti to be further discussed. The basal lineages (clade A and B) of Delibuti are solely distributed in the Australasia showing a presumable origin of the section in Australasia. Interestingly, clade D contains species from multiple continents in the Northern and Southern Hemispheres. Some species are distributed in Asia (Cortinarius sp., LC175538), in Europe (Cortinarius sp., JF907917), and South America, like Cortinarius sp. (MF599228) from Colombia and C. illitus M.M. Moser \& E. Horak, originally described from Argentina (Moser \& Horak, 1975), but also found in North America (according to the sequences in GenBank).These patterns could explain that the evolution of sect. Delibuti is limited to the

Peerj reviewing PDF | (2021:05:61287:1:1:NEW 11 Jul 2021) 
357

358

359

360

361

362

363

364

365

366

367

368

369

370

371

372

373

374

375

376

377

378

379

380

381

382

383

384

385

386

387

388

389

390

391

392

393

394

395

396

ectomycorrhizal host specificity, as well as geographic barriers (Wang \& Qiu, 2006; Brandrud, 1996; Wilson et al., 2017; Feng et al., 2016). The evolution and origin of sect. Delibuti, including the genus Cortinarius will be a subject for future research.

\section{Acknowledgements}

The authors are grateful to the two reviewers, Tai-Hui Li and Chang-Lin Zhao, for their constructive comments and suggestions on the manuscript. We thank to Dr. Rong Xie and Ms. Hui-Juan Sun (Tibet Academy of Agricultural and Animal Husbandry Sciences) and Mr. Ju-Zuo Li (Life Science College, Northeast Normal University) for their kind help in the fieldwork. We also thank to Mr. Ji-Peng Li and Yang Wang (Engineering Research Center of Edible and Medicinal Fungi, Ministry of Education, Jilin Agricultural University) for their kind help in the molecular studies.

\section{References}

Ariyawansa HA, Hyde KD, Jayasiri SC, Buyck B, Chethana KWT, Dai DQ, Dai YC, Daranagama DA, Jayawardena RS, Lücking R, Ghobad-Nejhad M, Niskanen T, Thambugala KM, Voigt K, Zhao RL, Li GJ, Doilom M, Boonmee S, Yang ZL, Cai Q, Cui YY, Bahkali AH, Chen J, Cui BK, Chen JJ, Dayarathne MC, Dissanayake AJ, Ekanayaka AH, Hashimoto A, Hongsanan S, Jones EBG, Larsson E, Li WJ, Li QR, Liu JK, Luo ZL, Maharachchikumbura SSN, Mapook A, McKenzie EHC, Norphanphoun C, Konta S, Pang KL, Perera RH, Phookamsak R, Phukhamsakda C, Pinruan U, Randrianjohany E, Singtripop C, Tanaka K, Tian CM, Tibpromma S, Abdel-Wahab MA, Wanasinghe DN, Wijayawardene NN, Zhang JF, Zhang H, AbdelAziz FA, Wedin M, Westberg M, Ammirati JF, Bulgakov TS, Lima DX, Callaghan TM, Callac P, Chang CH, Coca LF, Dal-Forno M, Dollhofer V, FliegerováK, Greiner K, Griffith GW, Ho H-M, Hofstetter V, Jeewon R, Kang JC, Wen T-C, Kirk PM, Kytövuori I, Lawrey JD, Xing J, Li H, Liu ZY, Liu XZ, Liimatainen K, Lumbsch HT, Matsumura M, Moncada B, Nuankaew S, Parnmen S, de Azevedo Santiago A LCM, Sommai S, Song Y, de Souza CAF, de Souza-Motta CM, Su HY, Suetrong S, Wang Y, Wei SF, Wen TC, Yuan HS, Zhou LW, RéblováM, Fournier J, Camporesi E, Luangsa-ard JJ, Tasanathai K, Khonsanit A, Thanakitpipattana D, Somrithipol S, Diederich P, Millanes AM, Common RS, Stadler M, Yan JY, Li XH, Lee HW, Nguyen TTT, Lee HB, Battistin E, Marsico O, Vizzini A, Vila J, Ercole E, Eberhardt U, Simonini G, Wen HA, Chen XH, Miettinen O, Spirin V, Hernawati. 2015. Fungal diversity notes 111-252- taxonomic and phylogenetic contributions to fungal taxa. Fungal diversity 75:27-274 DOI 10.1007/s13225-015-0346-5.

Ammirati J, Liimatainen K, Bojantchev D, Peintner U, Kuhnert-Finkernagel R, Cripps C, Dentinger D, Niskanen T. 2021. Cortinarius subgenus Leprocybe, unexpected diversity and significant differences in species compositions between western and eastern North America. Persoonia 46:216-239 DOI 10.3767/persoonia.2021.46.08. 
397

398

399

400

401

402

403

404

405

406

407

408

409

410

411

412

413

414

415

416

417

418

419

420

421

422

423

424

425

426

427

428

429

430

431

432

433

434

435

436

Bidaud A, Loizides M, Armada F, de Dios Reyes J, Carteret X, Corriol G, Consiglio G, Reumaux P, Bellanger J.-M. 2021. Cortinarius subgenus Leprocybe in Europe: expanded Sanger and Next Generation Sequencing unveil unexpected diversity in the Mediterranean. Persoonia 46:188-215 DOI 10.3767/persoonia.2021.46.07.

Bidaud A, Moënne-Loccoz P, Reumaux P. 1992. Atlas des Cortinaires IV. Meyzieu: Éditions Fédération Mycologique Dauphiné-Savoie.

Bidaud A, Moënne-Loccoz P, Reumaux P. 1994. Atlas des Cortinaires. Clé générale des sousgenres, sections, sous-sections et séries. Meyzieu: Éditions Fédération Mycologique Dauphiné-Savoie.

Brandrud TE. 1996. Cortinarius, subgenus Phlegmacium, section Phlegmacium in Europe. A study of character variation and ecology including a numerical analysis of the C. argutus complex. Mycological Research 100(4):471-485 DOI 10.1016/S0953-7562(96)80146-8.

Brandrud TE, Lindström H, Marklund H, Melot J, Muskos S. 1989. Cortinarius Flora Photographica I. Sweden: Cortinarius HB.

Cadiñanos JA, Gomez MM, Ballarà J. 2016. Cortinarius oreoborealis y C. pyrenaicus, dos nuevas especies de la seccion Myxacium, subgenero Myxacium (Fr.) Trog ss. str. Journal des JEC 18:39-65.

Consiglio G, Antonini D, Antonini M. 2003. Il Genere Cortinarius in Italia, Parte prima. Luglio: Associazione Micologica Bresadola.

Consiglio G. 2012. Il Genere Cortinarius in Italia, Parte sesta. Luglio: Associazione Micologica Bresadola.

Dima B, Lindström H, Liimatainen K, Olson A, Soop K, Kytövuori I, Dahlberg A, Niskanen T. 2016. Typification of Friesian names in Cortinarius sections Anomali, Spilomei and Bolares, and description of two new species from northern Europe. Mycological Progress 15(9):903-919 DOI 10.1007/s11557-016-1217-5.

Earle FS. 1902. A key to the North American species of Cortinarius I. Torreya 2(11):169-172 DOI 10.2307/40594021.

Felsenstein J. 1985. Confidence limits on phylogenies: An approach using the bootstrap. Evolution 39:783-791 DOI 10.2307/2408678.

Feng B, Zhao Q, Xu JP, Qin J, Yang ZL. 2016. Drainage isolation and climate change-driven population expansion shape the genetic structures of Tuber indicum complex in the Hengduan Mountains region. Scientific Reports 6:21811 DOI 10.1038/srep21811.

Fries EM. 1838. Epicrisis Systematis Mycologici. seu synopsis hymenomycetum. Uppsala.

Froslev TG, Brandrud TE, Jeppesen TS. 2006. New species and combinations in Cortinarius subgenus Phlegmacium section Calochroi. Mycotaxon 97:367-377.

Gardes M, Bruns TD. 1993. ITS primers with enhanced specificity for basidiomycetes. Application to the identification of mycorrhizae and rusts. Molecular Ecology 2(2):113-118 DOI 10.1111/j.1365-294X.1993.tb00005.x.

Garnica S, Schön ME, Abarenkov K, Riess K, Liimatainen K, Niskanen T, Dima B, Soop K, Frøslev TG, Jeppesen TS, Peintner U, Kühnert-Finkernagel R, Brandrud TE, Saar 
437

438

439

440

441

442

443

444

445

446

447

448

449

450

451

452

453

454

455

456

457

458

459

460

461

462

463

464

465

466

467

468

469

470

471

472

473

474

475

476

G, Oertel B, Ammirati JF. 2016. Determining threshold values for barcoding fungi lessons from Cortinarius (Basidiomycota), a highly diverse and widespread ectomycorrhizal genus. FEMS Microbiology Ecology 92:fiw045 DOI 10.1093/femsec/fiw045.

Garnica S, Weiß M, Oberwinkler F. 2003. Morphological and molecular phylogenetic studies in South American Cortinarius species. Mycological Research 107(10):1143-1156 DOI $10.1017 /$ S0953756203008414.

Garnica S, Weiß M, Oertel B, Oberwinkler F. 2005. A framework for a phylogenetic classification in the genus Cortinarius (Basidiomycota, Agaricales) derived from morphological and molecular data. Botany 83(11):1457-1477 DOI 10.1139/b05-107.

Garrido-Benavent I, Ballarà J, Liimatainen K, Dima B, Brandrud TE, Mahiques R. 2020. Cortinarius ochrolamellatus (Agaricales, Basidiomycota): a new species in C. sect. Laeti, with comments on the origin of its European-Hyrcanian distribution. Phytotaxa 640(3):185200 DOI 10.11646/phytotaxa.460.3.2.

Guan QX, Zhao CL. 2020. Two new corticioid species, Hyphoderma sinense and H. floccosum (Hyphodermataceae, Polyporales), from southern China. Mycosystema 40(3):447-461 DOI 10.13346/j.mycosystema.200382.

Hall TA. 1999. BioEdit: A user-friendly biological sequence alignment editor and analysis program for windows 95/98/NT. Nucleic Acids Symposium Series 41(41):95-98 DOI 10.1021/bk-1999-0734.ch008.

Harrower E, Ammirati JF, Cappuccino AA, Ceska O, Kranabetter JM, Kroeger P, Lim S, Taylor T, Berbee ML. 2011. Cortinarius species diversity in British Columbia and molecular phylogenetic comparison with European specimen sequences. Botany 89(11):799-810 DOI 10.1139/b11-065.

Harrower E, Bougher NL, Henkel TW, Horak E, Matheny PB. 2015. Long-distance dispersal and speciation of Australasian and American species of Cortinarius sect. Cortinarius. Mycologia 107(4):697-709 DOI 10.3852/14-182.

Horak E. 1983. Mycogeography in the South Pacifc region: Agaricales, Boletales. Australian Journal of Botany 10:1-41 DOI 10.1071/BT8310001.

Kibby G. 2005. Fungal Portraits: No. 21: Cortinarius betulinus. Field Mycology 6(1):3-4 DOI 10.1016/S1468-1641(10)60282-4.

Kornerup A, Wanscher JHK. 1978. The methuen handbook of colour. London: Eyre Methuen Ltd. Reprint.

Kumar S, Stecher G, Li M, Knyaz C, Tamura K. 2018. MEGA X: Molecular Evolutionary Genetics Analysis across computing platforms. Molecular Biology and Evolution 35(6):1547-1549 DOI 10.1093/molbev/msy096.

Li Y, Azbukina ZM. 2011. Fungi of Ussuri river valley. Beijing: Science Press.

Liimatainen K, Niskanen T, Dima B, Kytövuori I, Ammirati JF, Frøslev TG. 2014. The largest type study of Agaricales species to date: bringing identification and nomenclature of Phlegmacium (Cortinarius) into the DNA era. Persoonia 33:98-140 DOI 10.3767/003158514X684681. 
477

478

479

480

481

482

483

484

485

486

487

488

489

490

491

492

493

494

495

496

497

498

499

500

501

502

503

504

505

506

507

508

509

510

511

512

513

514

515

516

Luo Y, Bau T. 2021. Cortinarius jiaoheensis (Cortinariaceae), a new species of Cortinarius subgenus Telamonia section Flexipedes, from northeast China. Phytotaxa 494(1):113-121 DOI 10.11646/phytotaxa.494.1.7.

Moser M, Horak E. 1975. Cortinarius und nahe verwandte Gattungen in Südamerika. Beihefte zur Nova Hedwigia 52:1-628.

Nei M, Kumar S. 2000. Molecular Evolution and Phylogenetics. New York: Oxford University Press.

Niskanen T. 2008. Cortinarius subgenus Telamonia p.p. in North Europe. PhD. Thesis, University of Helsinki.

Niskanen T, Douglas B, Kirk P, Crous P, Lücking R, Matheny PB, Cai L, Hyde K, Cheek M. 2018. New discoveries: species of fungi described in 2017. In: Willis KJ, ed. State of the World's Fungi 2018, Report. London: Royal Botanic Gardens, Kew, 18-23.

Niskanen T, Kytövuori I, Bendiksen E, Bendiksen K, Brandrud TE, Frøslev TG, Høiland K, Jeppesen TS, Liimatainen K, Lindström H. 2008. Cortinarius (Pers.) Gray. In: Knudsen H, Vesterholt J, ed. Funga Nordica. Agaricoid, boletoid, clavarioid, cyphelloid and gastroid genera. Copenhagen: Nordsvamp, 676-677.

Niskanen T, Kytövuori I, Liimatainen K, Ammirati JF. 2015. Nomenclatural novelties. Index Fungorum 256:1-2

http://www.indexfungorum.org/Publications/Index\%20Fungorum\%20no.256.pdf.

Nylander JAA, Zoology S, Posada D, Mrmodeltest R, Os F. 2008. MrModeltest 2.3 README, May 222008.

Orton PD. 1955. Cortinarius I. Leeds: The Naturalist.

Osmundson TW, Robert VA, Schoch CL, Baker LJ, Smith A, Robich G, Mizzan L, Garbelotto MM. 2013. Filling gaps in biodiversity knowledge for macrofungi: contributions and assessment of an herbarium collection DNA barcode sequencing project. PLoS One 8(4):e62419 DOI 10.1371/journal.pone.0062419.

Peintner U, Bougher NL, Castellano MA, Moncalvo JM, Moser MM, Trappe JM, Vilgalys R. 2001. Multiple origins of sequestrate fungi related to Cortinarius (Cortinariaceae). American Journal of Botany 88(12):2168-2179 DOI 10.2307/3558378.

Peintner U, Dresch P, Bellù F, Borghi E. 2014. Cortinarius microglobisporus (Basidiomycota), a new species with roundish spores related to C. illuminus. Mycological Progress 13(3):899-904 DOI 10.1007/s11557-014-0975-1.

Peintner U, Horak E, Moser MM, Vilgalys R. 2002. Phylogeny of Rozites, Cuphocybe and Rapacea inferred from ITS and LSU rDNA sequences. Mycologia 94(4):620-629 DOI 10.1080/15572536.2003.11833190.

Peintner U, Moncalvo JM, Vilgalys R. 2004. Toward a better understanding of the infrageneric relationships in Cortinarius (Agaricales, Basidiomycota). Mycologia 96(5):1042-1058 DOI 10.1080/15572536.2005.11832904.

Peintner U, Moser MM, Thomas KA, Manimohan P. 2003. First records of ectomycorrhizal Cortinarius species (Agaricales, Basidiomycetes) from tropical India and their phylogenetic

Peer] reviewing PDF | (2021:05:61287:1:1:NEW 11 Jul 2021) 
517

518

519

520

521

522

523

524

525

526

527

528

529

530

531

532

533

534

535

536

537

538

539

540

541

542

543

544

545

546

547

548

549

550

551

552

553

554

555

556

position based on rDNA ITS sequences. Mycological Research 107(PT4):485-494 DOI $10.1017 /$ S0953756203007585.

Ronquist F, Huelsenbeck JP. 2003. MrBayes 3: Bayesian phylogenetic inference under mixed models. Bioinformatics 19(12):1572-1574 DOI 10.1093/bioinformatics/btg180.

Sawyer NA, Chambers SM, Cairney JWG. 1999. Molecular investigation of genet distribution and genetic variation of Cortinarius rotundisporus in eastern Australian sclerophyll forests. New Phytologist 142(3):561-568 DOI 10.1046/j.1469-8137.1999.00417.x.

Shao LP, Xiang CT. 1997. Forest Mushrooms of China. Haerbin: Northeast Forestry University Press.

Silvestro D, Michalak I. 2012. RaxmlGUI: a graphical front-end for RAxML. Organisms Diversity \& Evolution 12:335-337 DOI 10.1007/s13127-011-0056-0.

Soop K. 1990. Observationer av några intressanta Cortinarius-arter. Agarica 10/11(19/20):30 43.

Soop K. 2013. Cortinarioid fungi of New Zealand, 9th edn. Sweden: Éditions Scientrix.

Soop K. 2014. Cortinarius in Sweden, 14th edn. Sweden: Éditions Scientrix.

Soop K. 2016. A contribution to the study of the cortinarioid mycoflora of New Zealand, VII. New Zealand Journal of Botany 54(3):344-365 DOI 10.1080/0028825X.2016.1178149.

Soop K, Dima B, Cooper JA, Park D, Oertel B. 2019. A phylogenetic approach to a global supraspecific taxonomy of Cortinarius (Agaricales) with an emphasis on the southern mycota. Persoonia 42:261-290 DOI 10.3767/persoonia.2019.42.10.

Soop K, Wallace M, Dima B. 2018. New Cortinarius (Agaricales) species described from New Zealand. New Zealand Journal of Botany 56(2):163-182 DOI 10.1080/0028825X.2018.1436574.

Stamatakis A. 2014 RAxML version 8: a tool for phylogenetic analysis and post-analysis of large phylogenies. Bioinformatics 30:1312-1313 DOI 10.1093/bioinformatics/btu033.

Stensrud Ø, Orr RJS, Reier-Røberg K, Schumacher T, Høiland K. 2014. Phylogenetic relationships in Cortinarius with focus on North European species. Karstenia 54:57-71 DOI 10.29203/KA.2014.464

Teasdale SE, Beulke AK, Guy PL, Orlovich DA. 2013. Environmental barcoding of the ectomycorrhizal fungus Cortinarius. Fungal Diversity 58(1):299-310 DOI 10.1007/s13225012-0218-1.

Thompson JD, Gibson TJ, Plewniak F, Jeanmougin F, Higgins DG. 1997. The Clustal_X windows interface: flexible strategies for multiple sequence alignment aided by quality analysis tools. Nucleic Acids Research 25(24):4876-4882 DOI 10.1093/nar/25.24.4876.

Teng SC. 1963. Fungi of China. Beijing: Science Press.

Trog JG. 1844. Verzeichniss schweizerischer Schwämme, welche grösstentheils in der Umgebung von Thun gesammelt worden sind. Mitteilungen der Naturforschenden Gesellschaft Bern 1844(15-23):17-92.

Wang B, Qiu YL. 2006. Phylogenetic distribution and evolution of mycorrhizas in land plants. Mycorrhiza 16:299-363 DOI 10.1007/s00572-005-0033-6.

Peer] reviewing PDF | (2021:05:61287:1:1:NEW 11 Jul 2021) 
557

558

559

560

561

562

563

564

565

566

567

568

569

570

571

572

573

574

575

576

577

578

579

580

581

582

583

584

585

586

587

588

589

590

591

592

593

594

595

596

Wang K, Zhao MJ, Su JH, Yang L, Deng H, Wang YH, Wu HJ, Li Y, Wu HM, Wei XD, Wei TZ, Cai L, Yao YJ. 2020. The use of Checklist of Fungi in China database in the red list assessment of macrofungi in China. Biodiversity Science 28(1):74-98 DOI 10.17520/biods.2019163.

Wei TZ, Yao YJ. 2013. Cortinarius korfii, a new species from China. Mycosystema 32(3):557562 DOI 10.13346/j.mycosystema.2013.03.017.

White TJ, Bruns T, Lee S, Taylor J. 1990. Amplification and direct sequencing of fungal ribosomal RNA genes for phylogenetics. In: Innis MA, Gelfand DH, Sninsky JJ, White TJ, ed. PCR protocols: a guide to methods and amplifcations. New York: Academic Press.

Wilson AW, Hosaka K, Mueller GM. 2017. Evolution of ectomycorrhizas as a driver of diversification and biogeographic patterns in the model mycorrhizal mushroom genus Laccaria. New Phytologist 213:1862-1873 DOI 10.1111/nph.14270.

Wright SH, Berch SM, Berbee ML. 2009. The effect of fertilization on the below-ground diversity and community composition of ectomycorrhizal fungi associated with western hemlock (Tsuga heterophylla). Mycorrhiza 19(4): 267-276 DOI 10.1007/s00572-008-0218$\mathrm{x}$.

Xie ML. 2018. Resources and taxonomy of Cortinarius in northeast of China. MA. Thesis, Jilin Agricultural University.

Xie ML, Li D, Wei SL, Ji RQ, Li Y. 2019. Cortinarius subcaesiobrunneus sp. nov., (Cortinariaceae, Agaricales) a new species from northwest China. Phytotaxa 392(3):217224 DOI 10.11646/phytotaxa.392.3.4.

Xie ML, Wei TZ, Dima B, Fu YP, Ji RQ, Li Y. 2021. Cortinarius khinganensis (Agaricales), a new species of section Illumini from Northeast China. Phytotaxa 500(1): 1-10. DOI 10.11646/phytotaxa.500.1.1

Xie ML, Wei TZ, Fu YP, Li D, Qi LL, Xing PJ, Cheng GH, Ji RQ, Li Y. 2020. Three new species of Cortinarius subgenus Telamonia (Cortinariaceae, Agaricales) from China. MycoKeys 69:91-109 DOI 10.3897/mycokeys.69.49437.

Yuan HS, Lu X, Dai YC, Hyde KD, Kan YH, Kušan I, He SH, Liu NG, Sarma VV, Zhao CL, Cui BK, Yousaf N, Sun GY, Liu SY, Wu F, Lin CG, Dayarathne MC, Gibertoni TB, Conceição LB, Garibay-Orijel R, Villegas-Ríos M, Salas-Lizana R, Wei TZ, Qiu JZ, Yu ZF, Phookamsak R, Zeng M, Paloi S, Bao DF, Abeywickrama PD, Wei DP, Yang J, Manawasinghe IS, Harishchandra D, Brahmanage RS, de Silva NI, Tennakoon DS, Karunarathna A, Gaforov Y, Pem D, Zhang SN, de Azevedo Santiago ALCM, Bezerra JDP, Dima B, Acharya K, Alvarez-Manjarrez J, Bahkali AH, Bhatt VK, Brandrud TE, Bulgakov TS, Camporesi E, Cao T, Chen YX, Chen YY, Devadatha B, Elgorban AM, Fan LF, Du X, Gao L, Gonçalves CM, Gusmão LFP, Huanraluek N, Jadan M, Jayawardena RS, Khalid AN, Langer E, Lima DX, de LimaJúnior NC, de Lira CRS, Liu JK, Liu S, Lumyong S, Luo ZL, Matočec N, Niranjan M, Oliveira-Filho JRC, Papp V, Pérez-Pazos E, Phillips AJL, Qiu PL, Ren YH, Ruiz RFC, Semwal KC, Soop K, de Souza CAF, Souza-Motta CM, Sun LH, Xie ML, Yao 
597 YJ, Zhao Q, Zhou LW. 2020. Fungal diversity notes 1277-1386: taxonomic and 598 phylogenetic contributions to fungal taxa. Fungal Diversity 104:1-266 DOI $599 \quad$ 10.1007/s13225-020-00461-7.

600 Yuan ML, Sun PQ. 1995. Sichuan Mushroom. Chengdu: Sichuan Science and Technology 601 Press. 


\section{Figure 1}

ML phylogram inferred from nrDNA ITS sequence data.

The tree is rooted with sect. Cyanites. The Bayesian posterior probabilities (BPP) $\geq 0.95, \mathrm{ML}$ bootstrap values (ML) $\geq 75 \%$ and MP bootstrap values (MP) $\geq 75 \%$ are shown on the branches (BPP/ML/MP). New species is marked by blue bold. 


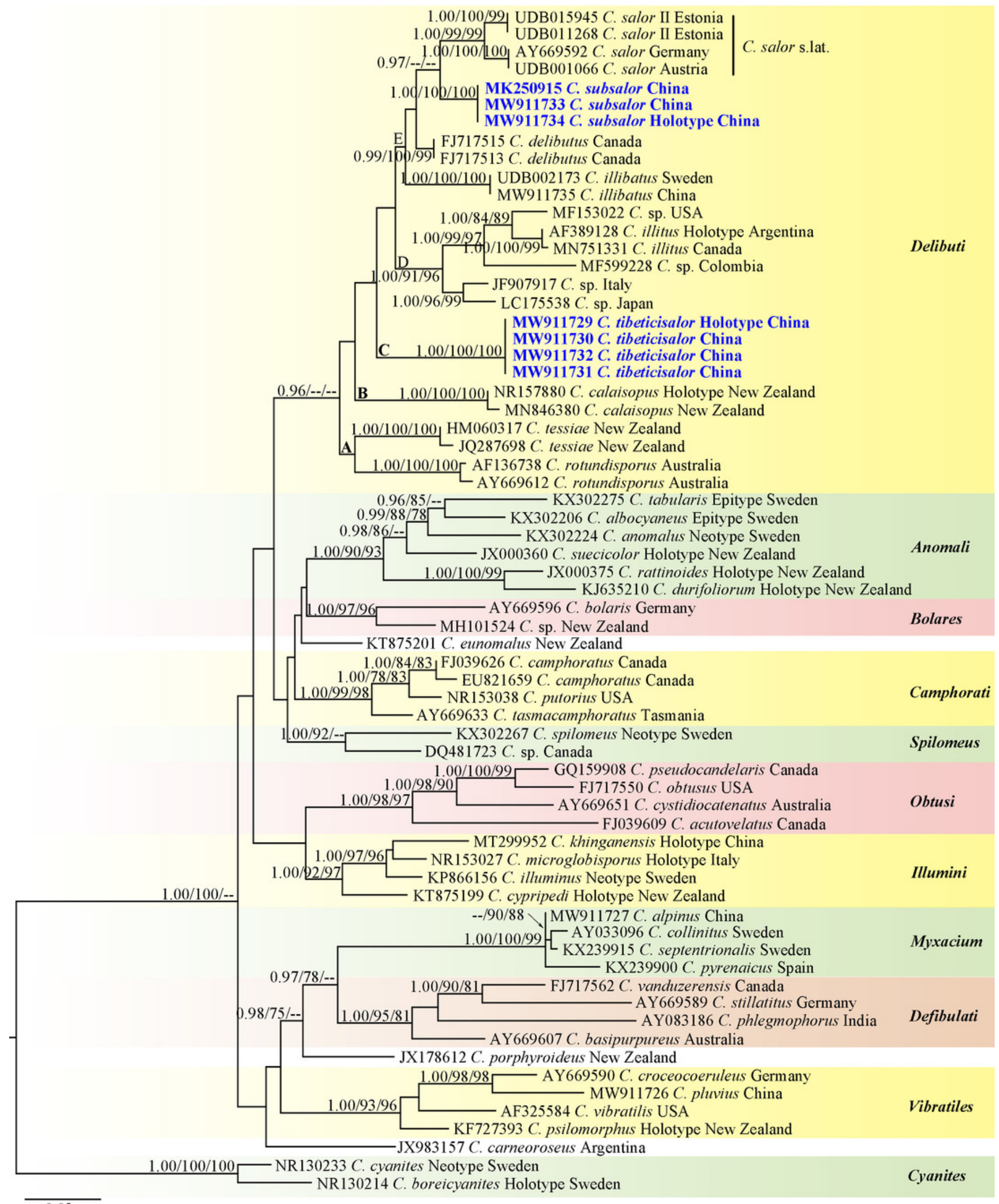


Figure 2

Cortinarius susalor.

(A) HMJAU48759 (Holotype). (B) HMJAU48758. (C, E) Basidiospores (HMJAU48759). (D, F) Pileipellis (HMJAU48759). (Photos: A. J.L. Chen; B-F. M.L. Xie). 

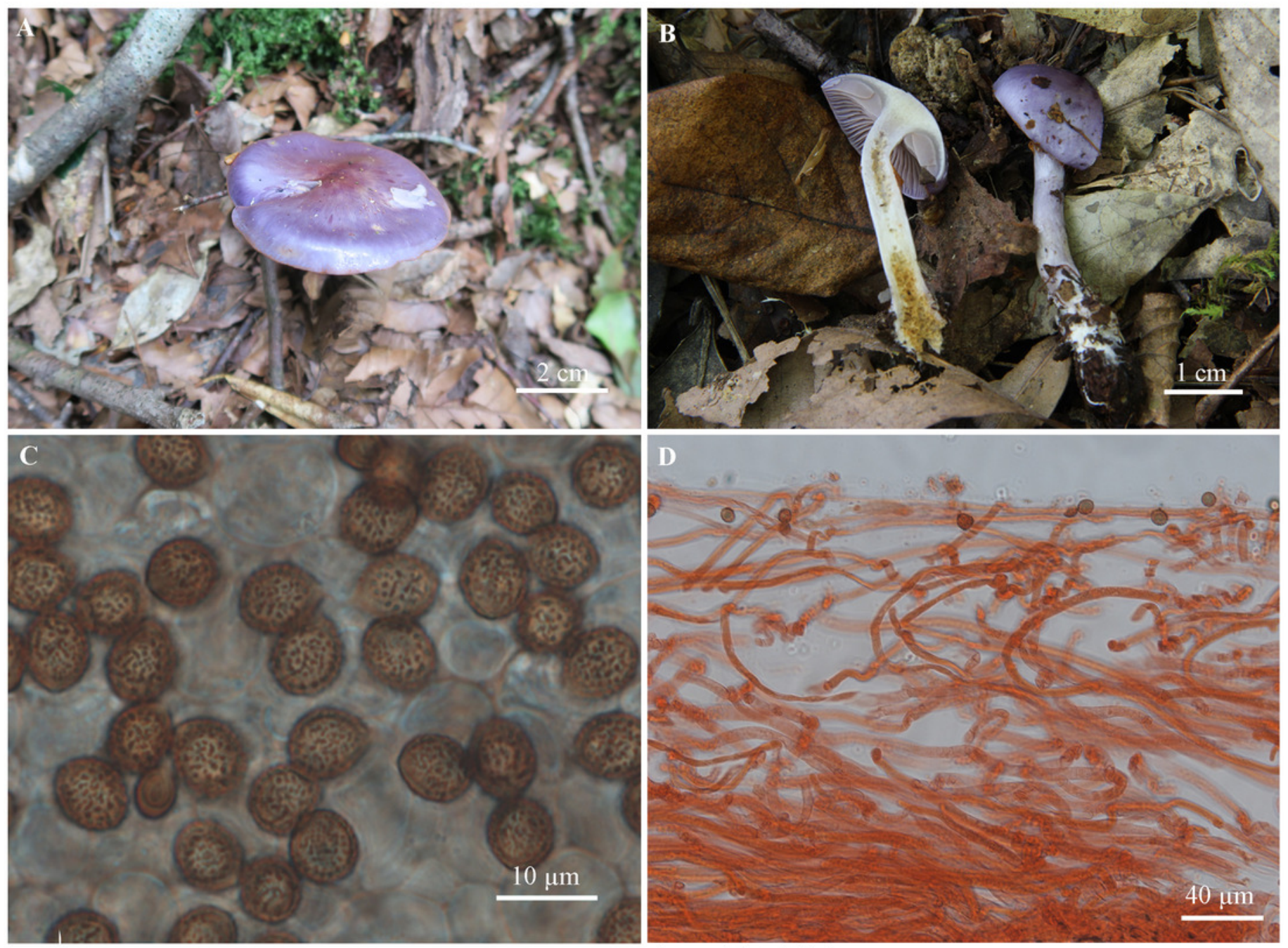

E
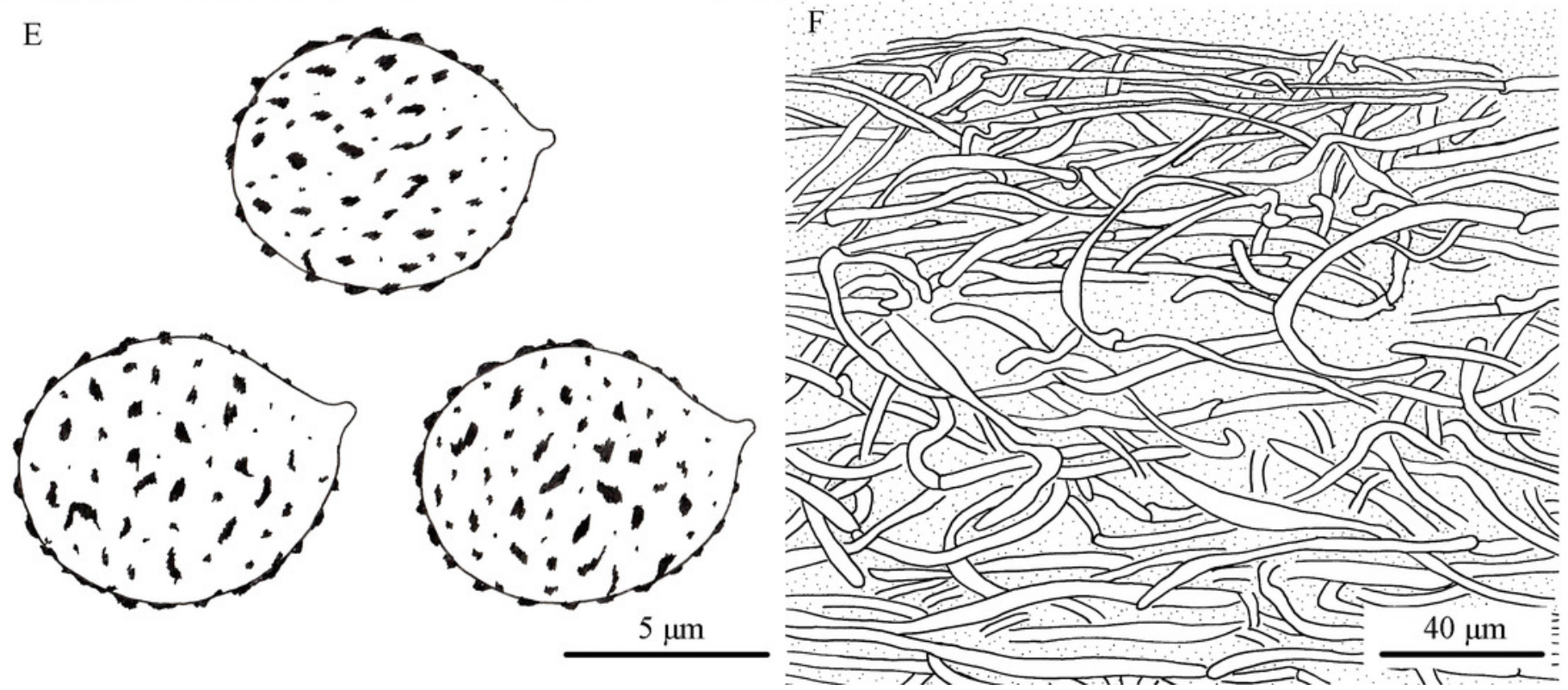
Figure 3

Cortinarius tibeticisalor.

(A) HMJAU48764 (Holotype). (B) HMJAU48762. (C, E) Basidiospores (HMJAU48764). (D, F) Pileipellis (HMJAU48764). (Photos: M.L. Xie). 

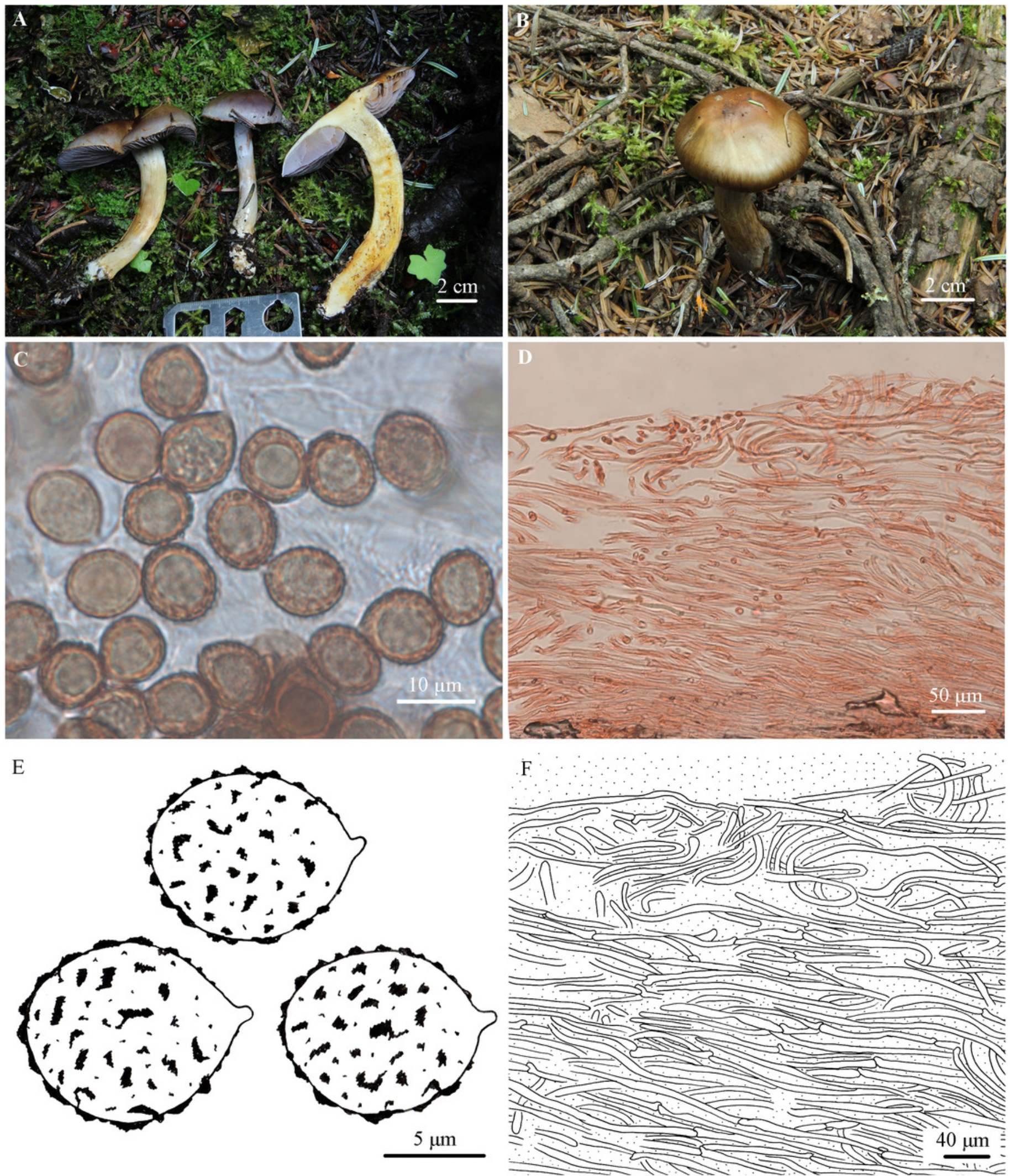


\section{Table 1 (on next page)}

ITS sequences used in the phylogenetic analyses.

New species is in bold. 
1

\begin{tabular}{|c|c|c|c|c|}
\hline Species & Voucher & Locality & $\begin{array}{l}\text { Accession } \\
\text { No. }\end{array}$ & References \\
\hline C. acutovelatus & F16388 (UBC) & Canada & FJ039609 & Harrower et al. (2011) \\
\hline C. albocyaneus Epitype & CFP1177 (S) & Sweden, Jämtland & KX302206 & Dima et al. (2016) \\
\hline C. alpinus & HMJAU44407 & China, Inner Mongolia & MW911727 & This study \\
\hline C. anomalus Neotype & CFP1154 (S) & Sweden, Ångermanland & KX302224 & Dima et al. (2016) \\
\hline C. basipurpureus & PERTH 04259629 & Australia & AY669607 & Garnica et al. (2005) \\
\hline C. bolaris & TUB 0118524 & Germany & AY669596 & Garnica et al. (2005) \\
\hline C. boreicyanites Holotype & CFP931 (S) & Sweden, Jämtland & NR130214 & Liimatainen et al. (2014) \\
\hline C. calaisopus & 60224 (OTA) & New Zealand & MN846380 & GenBank \\
\hline C. calaisopus Holotype & PDD 94050 & New Zealand, Dunedin & NR157880 & GenBank \\
\hline C. camphoratus & DAVFP26155 & Canada & EU821659 & Harrower et al. (2011) \\
\hline C. camphoratus & SMI193 & Canada & FJ039626 & Harrower et al. (2011) \\
\hline C. carneoroseus & EN76 (CORD) & Argentina & JX983157 & GenBank \\
\hline C. collinitus & IB 19940257 & Sweden & AY033096 & Peintner et al. (2002) \\
\hline C. croceocoeruleus & TUB 011833 & Germany & AY669590 & Garnica et al. (2005) \\
\hline C. cyanites Neotype & AT2005069 (UPS) & Sweden, Uppland & NR130233 & Liimatainen et al. (2014) \\
\hline C. cypripedi Holotype & PDD 107723 & New Zealand, Otago & KT875199 & Soop (2016) \\
\hline C. cystidiocatenatus & HO A20518A6 & Australia, Tasmania & AY669651 & Garnica et al. (2005) \\
\hline C. delibutus & F17048 (UBC) & Canada & FJ717515 & Harrower et al. (2011) \\
\hline C. delibutus & SAT01-301-12 & USA & FJ717513 & Harrower et al. (2011) \\
\hline C. durifoliorum Holotype & PDD 101829 & New Zealand, Westland & KJ635210 & Soop, Wallace \& Dima (2018) \\
\hline C. eunomalus & PDD 107706 & New Zealand & KT875201 & GenBank \\
\hline C. illibatus & HMJAU48760 & China, Heilongjiang & MW911735 & This study \\
\hline C. illibatus & AT2004220 (UPS) & Sweden & UDB002173 & UNITE \\
\hline C. illitus Holotype & IB 19630414 & Argentina & AF389128 & Peintner, Moncalvo \& Vilgalys \\
\hline C. illitus & MQ19-CMMF003109 & Canada, Quebec & MN751331 & GenBank \\
\hline C. illuminus Neotype & $\mathrm{F} 44877(\mathrm{~S})$ & Sweden & KP866156 & Niskanen et al. (2015) \\
\hline C. khinganensis Holotype & HMJAU44507 & China, Inner Mongolia & MT299952 & Xie et al. (2021) \\
\hline C. microglobisporus Holotype & IB 20110123 & Italy & NR153027 & Peintner et al. (2014) \\
\hline C. obtusus & SAT00-298-30 & USA & FJ717550 & Harrower et al. (2011) \\
\hline C. phlegmophorus & Typus-M3 & India & AY083186 & Peintner et al. (2003) \\
\hline C. pluvius & HMJAU44391 & China, Inner Mongolia & MW911726 & This study \\
\hline C. porphyroideus & 61406 (OTA) & New Zealand & JX178612 & Teasdale et al. (2013) \\
\hline C. pseudocandelaris & F17165 OC93 (UBC) & Canada, BC & GQ159908 & Harrower et al. $(2011)$ \\
\hline C. psilomorphus Holotype & PDD 103885 & New Zealand & KF727393 & Soop (2016) \\
\hline C. putorius Holotype & TN 07-411 (H) & USA & NR153038 & Ariyawansa et al. (2015) \\
\hline C. pyrenaicus & JB-8573/15 & Spain, Gisclareny & KX239900 & Cadiñanos, Gomez \& Ballarà (2016) \\
\hline C. rattinoides Holotype & PDD 88283 & New Zealand & JX000375 & GenBank \\
\hline C. rotundisporus & PERTH 05255074 & Australia & AY669612 & Garnica et al. (2005) \\
\hline C. rotundisporus & G12 & Australia & AF136738 & Sawyer, Chambers \& Cairney (1999) \\
\hline C. salor & IB 19940297 & Austria & UDB001066 & Peintner et al. $(2001)$ \\
\hline C. salor & TUB 011838 & Germany & AY669592 & Garnica et al. (2005) \\
\hline C. salor II & TUF106868 & Estonia & UDB011268 & UNITE \\
\hline
\end{tabular}




\begin{tabular}{|c|c|c|c|c|}
\hline C. salor II & TAAM128516 & Estonia & UDB015945 & UNITE \\
\hline C. septentrionalis & ARAN Fungi03516 & Sweden, Harjedalen & KX239915 & Cadiñanos, Gomez \& Ballarà (2016) \\
\hline C. spilomeus Neotype & TEB CFP1137 (S) & Sweden & KX302267 & Dima et al. (2016) \\
\hline C. stillatitus & TUB 011587 & Germany & AY669589 & Garnica et al. (2005) \\
\hline C. subsalor & HMJAU48758 & China, Zhejiang & MW911733 & This study \\
\hline C. subsalor Holotype & HMJAU48759 & China, Zhejiang & MW911734 & This study \\
\hline C. subsalor & MHHNU 30409 & China, Hunan & MK250915 & GenBank \\
\hline C. suecicolor Holotype & PDD 74698 & New Zealand & $\mathrm{JX} 000360$ & GenBank \\
\hline C. tabularis Epitype & CFP949 (S) & Sweden & KX302275 & Dima et al. (2016) \\
\hline C. tasmacamphoratus & HO A20606A0 & Tasmania & AY669633 & Garnica et al. (2005) \\
\hline C. tessiae & PDD 94054 & New Zealand, Dunedin & JQ287698 & GenBank \\
\hline C. tessiae & PDD 72611 & New Zealand & HM060317 & GenBank \\
\hline C. tibeticisalor & HMJAU48761 & China, Tibet & MW911731 & This study \\
\hline C. tibeticisalor & HMJAU48762 & China, Tibet & MW911732 & This study \\
\hline C. tibeticisalor & HMJAU48763 & China, Tibet & MW911730 & This study \\
\hline C. tibeticisalor Holotype & HMJAU48764 & China, Tibet & MW911729 & This study \\
\hline C. vanduzerensis & VMS28 & Canada & FJ717562 & Harrower et al. (2011) \\
\hline C. vibratilis & IB 19970078 & USA & AF325584 & Peintner et al. (2001) \\
\hline C. sp. & CSU CO 2476 & Colombia, Antioquia & MF599228 & GenBank \\
\hline C. sp. & FLAS-F-60161 & USA & MF153022 & GenBank \\
\hline C. sp. & YM714 & Japan, Hokkaido & LC175538 & GenBank \\
\hline C. sp. & 1780 & Italy & JF907917 & Osmundson et al. (2013) \\
\hline C. sp. & SWUBC500 & Canada & DQ481723 & Wright, Berch \& Berbee (2009) \\
\hline C. sp. & PDD 72685 & New Zealand & MH101524 & GenBank \\
\hline
\end{tabular}

